\title{
Profile of Metabolic Syndrome at CNHU HKM Cotonou
}

\author{
Annelie Kerekou-Hode ${ }^{1}$, Philippe Adjagba ${ }^{2}$, Dolorès Falolou2 ${ }^{2}$, Bénédicte Attolou² \\ ${ }^{1}$ University Clinic of Endocrinology, National University Hospital Center Hubert Koutoukou Manga, Cotonou, Benin \\ ${ }^{2}$ University Cardiology Clinic, National University Hospital Center Hubert Koutoukou Manga, Cotonou, Benin \\ Email: kerekouannelie@yahoo.fr, dotoup@yahoo.fr, faldolf80@gmail.com, benedicteattolou43@yahoo.com
}

How to cite this paper: Kerekou-Hode, A. Adjagba, P., Falolou, D. and Attolou, B. (2019) Profile of Metabolic Syndrome at CNHU HKM Cotonou. Open Journal of Endocrine and Metabolic Diseases, 9, 127-133. https://doi.org/10.4236/ojemd.2019.912013

Received: December 1, 2019

Accepted: December 28, 2019

Published: December 31, 2019

Copyright (c) 2019 by author(s) and Scientific Research Publishing Inc. This work is licensed under the Creative Commons Attribution International License (CC BY 4.0).

http://creativecommons.org/licenses/by/4.0/

(c) (i) Open Access

\begin{abstract}
The metabolic syndrome combines morphological, physiological and biochemical abnormalities that evolve over time, predisposing the affected person to atherosclerosis and its complications. The purpose of our work was to determine the clinical and biological profile of metabolic syndrome in patients received for medical examination according to WHO criteria. This was a retrospective study over a 1-year period: from January 1st, 2018 to December 31st, 2018. The information collected was clinical (sociodemographic characteristics, anthropometric data, initial blood pressure, cardiovascular history) and biological data (fasting blood glucose level, lipid test). Two thousand six hundred and two patients visited during the study period, including $291 \mathrm{pa}-$ tients $(11.18 \%)$ for a reason that may evoke the metabolic syndrome but 115 files were retained for this study. The age of the patients was $58.39 \pm 10.02$ years with extremes ranging from 32 to 81 years old. Metabolic syndrome was found in 77 patients, or $66.9 \%$ of patients who had consulted for a reason that might suggest this diagnosis. $44.3 \%$ had 3 criteria for definition; $19.1 \%$ had 4 criteria and 3.5\% had 5 criteria. All patients have benefited a mono, bi or antihypertensive therapy associated with antidiabetic or hypolipemic treatment. Metabolic syndrome better predicts cardiovascular risk than analysis of individual risk factors. Its prevention involves diet which must be hyposodium, hypolipidic, without fast sugar and daily physical activities.
\end{abstract}

\section{Keywords}

High Blood Pressure, Diabetes, Obesity, Dyslipidemia, Benin Republic

\section{Introduction}

The unintended nature of the combination of obesity, diabetes, high blood pressure and hyperuricemia was highlighted by several authors during the first half 
of the 20th century [1]. The term Metabolic Syndrome was created in 1975 by Hermann Haller and Markolf Hanefeld [2]. The "X-syndrome" formulated by Gerald M. Reaven around insulin resistance was the first well-structured version of the metabolic syndrome in 1988 [3]. Due to the increase in the prevalence of obesity over the last decade, five definitions have been proposed by several groups to characterize the metabolic syndrome. It was recognized by the World Health Organization (WHO) in 1998 [4]. Metabolic syndrome combines morphological, physiological and biochemical abnormalities that evolve with time predisposing the affected subject to atherosclerosis and its complications. The prevalence of metabolic syndrome among hypertensive patients in Parakou was $69.6 \%$ according to the criteria of the International Diabetes Federation (IDF) and $65.2 \%$ according to those of the National Cholesterol Education Program (NCEP) [5]. It was 79\% among obese patients in Ouidah according to WHO criteria [6].

The purpose of our work was to determine the clinical and biological profile of metabolic syndrome in patients received for medical examination according to WHO criteria.

\section{Methodology}

This was a retrospective study over a 1-year period: from January 1st, 2018 to December 31st, 2018, involving patients who had consulted in endocrinology and cardiology units. A systematic review of medical records was completed. The information collected was clinical (sociodemographic characteristics, anthropometric data, initial blood pressure, cardiovascular history) and biological data (fasting blood glucose level, lipid test). Were considered diabetic patients already known and treated as such or whose fasting blood glucose level was greater than or equal to $1.26 \mathrm{~g} / \mathrm{l}$. The dyslipidemia was held in front of a total cholesterol level higher than $2.5 \mathrm{~g} / \mathrm{l}$ or a LDL cholesterol level higher than $1.15 \mathrm{~g} / \mathrm{l}$. The LDL-cholesterol level was obtained from Friedwald's formula by reporting the difference between total cholesterol and HDL-cholesterol at 1/5th of triglyceridemia (in grams per liter).

WHO's criteria were used for the determination of the metabolic syndrom. These criteria include visceral or central obesity, waist/hip circumference $>0.9$ (male) and 0.75 (female) and/or BMI $>30 \mathrm{~kg} / \mathrm{m}^{2}$. Records in which metabolic syndrome assessment parameters are completed, we chose BMI which was systematically estimated at our patients, associated with at least 2 of the following criteria:

- Blood glucose $>1 \mathrm{~g} / \mathrm{l}$;

- Blood pressure $\geq 140 \mathrm{mmHg}$;

- Triglyceride $\geq 1.50 \mathrm{~g} / \mathrm{l}$;

- HDL-Cholesterol (HDL-c) $<0.35 \mathrm{~g} / 1$ in men and $<0.39 \mathrm{~g} / \mathrm{l}$ in women.

The inclusion criteria were the records containing the above-mentioned parameters. We evaluated the effectiveness of treatment instituted with a follow-up 
of 6 months. The collection of files was made by a systematic questionnaire. Data analysis was performed using the software Epi-Info in version 3.5.4.

\section{Results}

Two thousand six hundred and two patients consulted during the study period, including 291 patients (11.18\%) for a reason that could evoke the metabolic syndrome. One hundred and fifteen records were usable in this study. Among the 115 cases there were 77 cases $(2.9 \%)$ of metabolic syndrome.

The population consisted of 115 patients with as many men as women. The age of the patients was $58.39 \pm 10.02$ years with extremes ranging from 32 to 81 years (Table 1). All patients had high blood pressure, of which $95.6 \%$ were known and treated. Twenty four patients (21.2\%) had type 2 diabetes and $18.6 \%$ had a history of dyslipidemia (Table 1$)$. Seventy nine patients $(77.4 \%)$ had obesity, including 59.1\% Grade I obesity and $18.3 \%$ Grade II obesity. Forty four patients $(39.1 \%)$ had hyperglycemia, 68 patients (59.1\%) had low cholesterol, and 22 patients (19.1\%) had high triglyceride levels.

Metabolic syndrome was found in 77 patients (66.9\%) who are distributed according to WHO criteria in Figure 1 and $44.3 \%$ had 3 criteria for definition; $19.1 \%$ had 4 criteria and $3.5 \%$ had 5 criteria. All patients have benefited a mono, bi- or antihypertensive therapy associated with antidiabetic or hypolipemic treatment. Evaluation of the patients at 6 months allowed to evaluate the prescribed treatment (Table 2 and Table 3). Hypertensive patients were controlled by their treatment in $78.7 \% ; 44.4 \%$ of diabetic patients were balanced and $55.8 \%$ had their lipid balance normalized. Weight results were relatively less noticeable with weight loss in only $35.9 \%$.

Table 1. Description of the population.

\begin{tabular}{cc}
\hline description parameter & \\
\hline Age (mean-age) & $58.39 \pm 10.02$ \\
Sex-ratio & 1.01 \\
\hline Medical history & $95.6 \%$ \\
\hline High blood pressure (history) & $21.2 \%$ \\
Type 2 Diabetes & $18.6 \%$ \\
Dyslipidelia & \\
\hline Métabolic syndrome (WHO criteria) & $31.15 \pm 4.68$ \\
BMI (mean) & $142.81 \pm 19.10$ \\
Systolic blood pressure & $84.86 \pm 12.60$ \\
Distolic blood pressure & $1.07 \pm 0.34$ \\
Glycemia & $0.47 \pm 0.14$ \\
Cholestérolemia HDL & $1.306 \pm 0.46$ \\
Cholestérolemia LDL & $1.02 \pm 0.49$ \\
Triglyceridemia & \\
\hline
\end{tabular}


Table 2. Prescribed treatment.

\begin{tabular}{ccc}
\hline & Number & Percentage \\
\hline Antihypertensive drugs & 95 & \\
\hline Calcium inhibitor & 63 & 83.3 \\
Conversion enzyme inhibitor & 39 & 55.3 \\
Diuretic & 27 & 34.2 \\
Beta blocker & 11 & 23.7 \\
\hline Oral anti-diabetic drugs & 6 & 9.6 \\
Biguanides & & 5.3 \\
Sulfonamides & 23 & 20.2 \\
\hline Lipid-lowering agent & & \\
\hline Statin & & \\
\hline
\end{tabular}

Table 3. Evolution.

\begin{tabular}{|c|c|c|}
\hline & Number & Percentage \\
\hline \multicolumn{3}{|c|}{ High BP controlled } \\
\hline Yes & 74 & 78.7 \\
\hline No & 20 & 21.3 \\
\hline Total & 94 & 100.0 \\
\hline \multicolumn{3}{|c|}{ Balance Diabetes } \\
\hline Yes & 8 & 44.4 \\
\hline No & 10 & 55.6 \\
\hline Total & 18 & 100.0 \\
\hline \multicolumn{3}{|c|}{ Lipid balance normalized } \\
\hline Yes & 29 & 55.8 \\
\hline No & 23 & 44.2 \\
\hline Total & 52 & 100.0 \\
\hline \multicolumn{3}{|c|}{ Abdominal obesity } \\
\hline Yes & 4 & 19.0 \\
\hline No & 17 & 81.0 \\
\hline Total & 21 & 100.0 \\
\hline \multicolumn{3}{|c|}{ Weigh loss } \\
\hline Yes & 14 & 35.9 \\
\hline No & 25 & 64.1 \\
\hline Total & 39 & 100.0 \\
\hline
\end{tabular}

\section{Discussion}

We conducted a retrospective hospital-based study, which constitutes a recruitment bias in the assessment of prevalence. The retrospective nature of the study did not systematically provide all the information needed to make a diagnosis of 


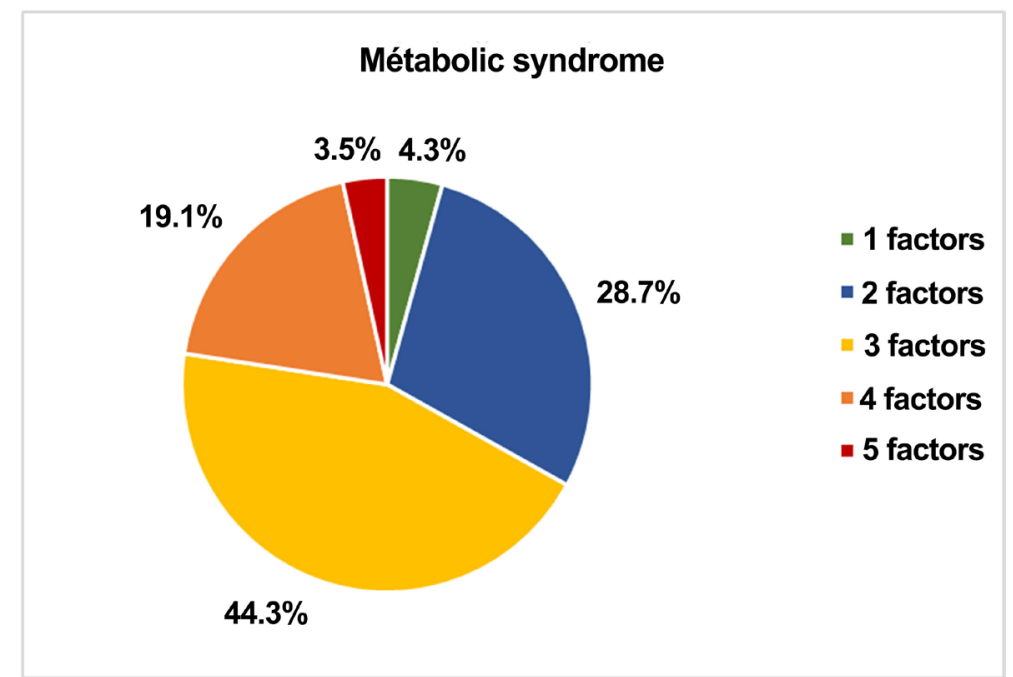

Figure 1. Classification of patients according to number of risk factors.

metabolic syndrome. Prevalence $2.9 \%$ is lower than the hospital prevalence of 4.94\% observed in Cote d'Ivoire [7]. And 17.5\% in Burkina faso in patients hospitalized for high blood pressure [8]. Prevalence is $8.9 \%$ in the general population in Senegal [9] and ranges from $6.1 \%$ in women to $10.2 \%$ in men in France [10]. This variation may be a reflection of the different socio-economic conditions in the countries, or related to the diet and the change of lifestyle of the different populations but also the difficulty of harmonizing the definition criteria. The mean age of the patients was $58.39 \pm 10.02$ years, similar to the mean age of $56.1 \pm 10.7$ years reported by Millogo in Burkina Faso [8]. Prevalence of metabolic syndrome increases with age thus, it is $5 \%$ in men vs. $2 \%$ in women under 40 and $14.1 \%$ vs. $12 \%$ after 70 years [10]. Mean systolic and diastolic BP were statistically higher as was mean BMI in the population of patients with metabolic syndrome. Millogo made the same observation in Burkina Faso [8], as well as Kant in India [11]. Similarly, blood glucose and triglycerides were on average higher and HDL cholesterol was on average lower than in the general population [11]. The most common risk factors were high blood pressure followed by obesity $77.4 \%$, low HDL cholesterol $59.1 \%$ and diabetes $39.1 \%$. In most studies, low HDL cholesterol was more common [7] [11] [12], which may reflect a lack of physical activity. The prevention of this factor is then important in the management of the metabolic syndrome.

\section{Conclusion}

Metabolic syndrome is a pathology that poses the problem on the one hand of its non-consensual definition and on the other hand that of the control of its constituent elements, especially high blood pressure. Metabolic syndrome better predicts cardiovascular risk than analysis of individual risk factors. Its prevention involves diet which must be hyposodium, hypolipidic, without fast sugar and daily physical activities. 


\section{Acknowledgements}

We would like to thank Assogba Brice for its statistical analysis.

\section{Conflicts of Interest}

The authors declare no conflicts of interest regarding the publication of this paper.

\section{References}

[1] Vialettes, B. (2015) Jean Vague (1911-2003): Un exemple de sérendipité au service de la nutrition et de la diabétologie. Médecine des Maladies Métaboliques, 9, 355-359. https://doi.org/10.1016/S1957-2557(15)30092-4

[2] Haller, H. and Hanefeld, M. (1975) Synoptische betrachtung metabolischer risikofaktoren. Haller H Hanefeld M Jaross W eds Lipidstoffwechselstörungen, 254-264.

[3] Reaven, G.M. (1988) Role of Insulin Resistance in Human Disease. Diabetes, 37, 1595-1607. https://doi.org/10.2337/diab.37.12.1595

[4] Alberti, K.G.M.M. and Zimmet, P.Z. (1998) Definition, Diagnosis and Classification of Diabetes Mellitus and Its Complications. Part 1: Diagnosis and Classification of Diabetes Mellitus. Provisional Report of a WHO Consultation. Diabetic Medicine, 15, 539-553. https://doi.org/10.1002/(SICI)1096-9136(199807)15:7<539::AID-DIA668>3.0.CO;2-S

[5] Assoumanou, M., Dovonou, A., Ngome, M. and Akpona, S. (2012) Prévalence du syndrome métabolique chez les sujets hypertendus adultes dans les formations sanitaires de Parakou (Bénin). International Journal of Biological and Chemical Sciences, 6, 1419-1427. https://doi.org/10.4314/ijbcs.v6i4.2

[6] Aniou Yessoufou, A.G., Ustin Behanzin, J., Djihoumeto, E., Isstina, Z.A., Élanie Ahokpe, M. and Lphonse Sezan, A. (2015) Aspects épidémiologiques du syndrome métabolique au sein de la population obèse de la Commune Ouidah au Sud-ouest du Bénin.

[7] Hauhouot-Attoungbre, M., Yayo, S., Ake-Edjeme, A., Yapi, H., Ahibo, H. and Monnet, D. (2008) Le syndrome métabolique existe-t-il en Côte d'Ivoire? Immuno-Analyse \& Biologie Spécialisée, 23, 375-378. https://doi.org/10.1016/j.immbio.2008.10.002

[8] Millogo, G.R.C., Samandoulougou, A., Yaméogo, N.V., Yaméogo, A.R., Kologo, K.J., Toguyeni, J.Y. and Zabsonré, P. (2014) Syndrome métabolique chez les patients hypertendus dans le service cardiologie du CHU Yalgado Ouedraogo de Ouagadougou, Burkina Faso. The Pan African Medical Journal, 19, 290.

https://doi.org/10.11604/pamj.2014.19.290.4028

[9] Sarr, A., Lopez-Sall, P., Ndour-Mbaye, N.-M., Diop, S.-N., Sarr, G.-N., Diop, O., Sall, N.-D., Touré, M., Cissé, A. and Sarr, A. (2012) Fréquence du syndrome plurimétabolique et des anomalies associées au sein d'une population noire au Sénégal: Frequency of metabolic syndrome in Black Africans, in Senegal. Médecine des Maladies Métaboliques, 6, 238-243. https://doi.org/10.1016/S1957-2557(12)70405-4

[10] Pannier, B., Thomas, F., Eschwege, E., Bean, K., Benetos, A., Leocmach, Y., Danchin, N. and Guize, L. (2006) Cardiovascular Risk Markers Associated with the Metabolic Syndrome in a Large French Population: The SYMFONIE Study. Diabetes \& metabolism, 32, 467-474. https://doi.org/10.1016/S1262-3636(07)70305-1

[11] Kant, R. and Khapre, M. (2019) Profile of Metabolic Syndrome in Newly Detected Hypertensive Patients in India: An Hospital-Based Study. International Journal of 
Applied and Basic Medical Research, 9, 32.

[12] Pemminati, S., Adhikari, P.M., Pathak, R. and Pai, M. (2010) Prevalence of Metabolic Syndrome (METS) Using IDF 2005 Guidelines in a Semi Urban South Indian (Boloor Diabetes Study) Population of Mangalore. Journal of Association physicians of India, 58, 674-677. 